\title{
Scanning of Organic Agricultural Products From Production and Market Side
}

\author{
Zaini Amin* and Andry \\ ${ }^{1}$ Program Studi Agribisnis, Universitas Musi Rawas \\ *e-mail: zaini_amin@ymail.com
}

\begin{abstract}
This research aims to: scan organic agricultural products from the production side, by comparing production and revenue through the application of two kinds organic fertilizers formulation; and scan from the market side, by observing marketing channels, and consumer responses to organic products produced. Both organic fertilizer formulations are obtained through the Linear Programming (LP) application that was conducted in May 2019-July 2019. Research conducted by the method of action research. For plants that need planting sweet corn, spinach, kale, and beans by applying both formulations in two experimental plots, with an area of respectively $40 \mathrm{~m} 2,14 \mathrm{~m} 2,14 \mathrm{~m} 2$, and $40 \mathrm{~m} 2$. Then, from the market side, crop yields are distributed through institutions involved in the marketing of these commodities, and then market data is obtained. The results show that, in terms of farm production and analysis, the provision of production can be done at a more competitive price, as indicated by high crop productivity, and minimal fertilizer costs; and from the market side, shows that $80 \%$ of distribution takes place through channels that require the services of intermediary traders, and consumer responses show that organic farming products are better than conventional agricultural products that they consumed previously.
\end{abstract}

Keywords: Market, Organic Agricultural, Scanning

Disubmit : 9 Februari 2021; Diterima : 20 Maret 2021; Disetujui : 22 April 2021

\section{INTRODUCTION}

Danger residues of synthetic chemicals present in plants have brought concern for some institutions dealing with consumer protection, including the government. However, some research shows that the decision to consume is very much determined by various considerations, including purchasing power, education level, and social conditions of the community.

Food consumption pattern preferences are largely determined by purchasing power and level of education, age, and drive for healthy living (Z. Amin, 2016; Iqbal, 2015). The decision to buy organic products for various ethnic groups is influenced by factors sociodemographic. In particular, ethnic Malay in high-income urban areas is strongly influenced by women, healthy living needs and prices. While ethnic Chinese and Indians, the decision to buy food is more focused on health needs (Kumar, P., A. Kumar, 2012; Qua, S.H., 2010). The decision to consume food in a patrilineal society is very much determined by the head of the household/father (Humaidi \& Amin, Zaini, 2015) For this health interest, consumers have the ability to buy organic products at a price more expensive than conventionally produced products (Z. Amin, Andry, Humaidi, Wahyuni, \& Ningsih, 2020) 
The decision to buy consumer products above relates to consumer preferences. This means that consumer preference is the choice of consumers for some existing products, and in terms of the attributes attached to the consumer goods referred to above.

Consumer preferences for organic food because it considers health, care for the environment, and the attributes inherent in organic food, including nutritional content, taste, freshness, and appearance, in addition to factors sociodemographic (Sivathanu, 2015) Furthermore, consumers' decision to buy organic vegetables is greatly influenced by price and income. This means to maximize the value of use, preferences are also determined by the price and income of consumers (Paradiba, D., M. Mappatoba, 2017) Previous findings explained that consumer confidence to pay for products is very influential on consumers' willingness to pay premium residual safe food products (Ameriana, 2006). Consumer perceptions of organic rice related to nutrition, taste, appearance are very positive, and farmers are willing to pay more than the actual price (Figure 1). However, this study was conducted on consumers with middle to upper-income levels, and the supply of organic rice is still far below demand (Z. Amin et al., 2020).

Moving on from the description above it can be concluded that the level of education and income significantly influences consumer preferences for organic products. Therefore, for the sake of food security and community nutrition provision, it is necessary to conduct counseling on organic food, which is integrated with an increase in cheaper production. (Z. Amin, 2016). shows that the decline in rice prices has led to an increase in farmers' real income, so consumers switch to superior goods (rice) as income effects.

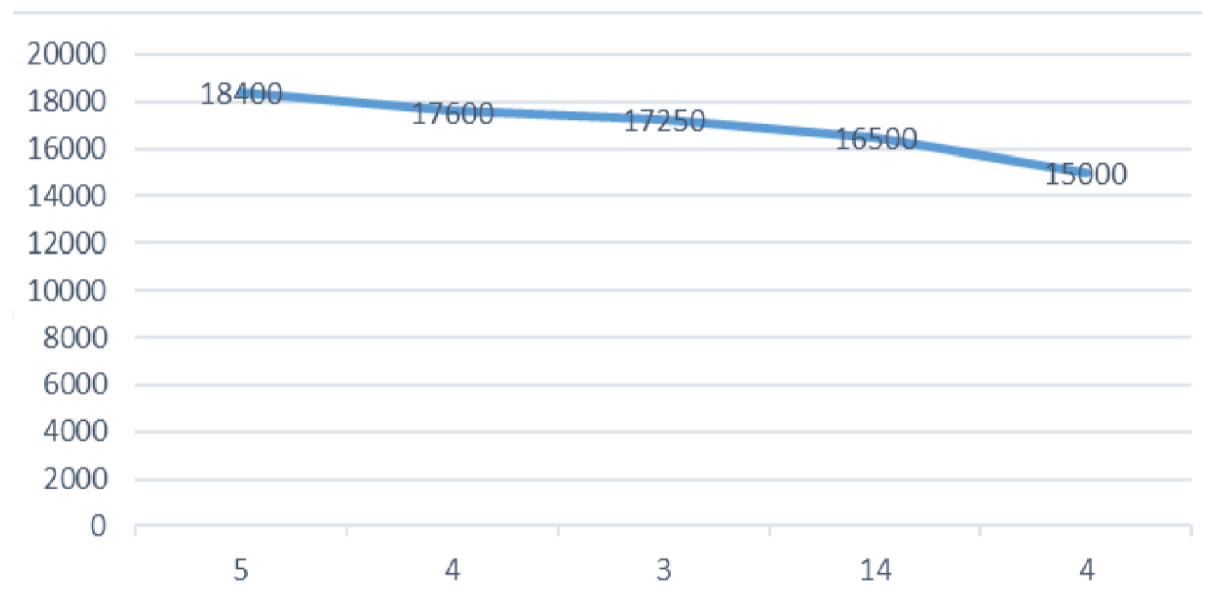

Figure 1. Consumer Willingness to Pay for Organic Rice (Amin, et al., 2020)

Apart from various considerations for consumers in consuming organic products above, for the government, it has the interest to protect consumers from the production and market side in providing safe, diverse and nutritious which is one part of building competitive human resources. For this reason, scanning organic agricultural products from production and marketing needs to be done.

\section{METHODS}

This research was conducted from May to July 2019 in Musi Rawas Village. The research method used is action research. The object of research is a farm trial plot in the field and marketing institutions, including consumers.

Data obtained from the application of crop planting sweet corn, spinach, kale, and beans by applying both formulations in two experimental plots, with an area of respectively $40 \mathrm{~m}^{2,} 14 \mathrm{~m}^{2,} 14 \mathrm{~m}^{2}$, and $40 \mathrm{~m}^{2}$. Both organic formulations were decomposed with bacterial decomposition technology (PBO), obtained by applying the Linear Programming Method (LP), so as to obtain a cost minimization solution. To accelerate the application of both formulations, then, from the market side, crop yields are distributed through 
institutions involved in the marketing of the commodity, which consists of collecting traders, two retailers, and 50 end consumers, to obtain market-side data.

Research data obtained from the production side, analyzed by tabulation, while from the market side, marketing channel data were analyzed descriptively, and consumer response data to organic agricultural products were analyzed using a Likert scale. According to (Umar, 2002) a Likert scale is an ordinal scale. To meet the above criteria, a Likert scale is arranged which relates to consumer responses to statements submitted: strongly agree (5), agree (4), simply agree (3), disagree (2), and strongly disagree (1). Then, to find out the consumer response category is done with the following mathematical formula:

$\mathrm{C}=\frac{\mathrm{X}_{\mathrm{i}}+\mathrm{X}_{\mathrm{n}}}{\mathrm{K}}$

Where:

$\mathrm{C}=$ Interval

$\mathrm{K}=$ Number of classes

$\mathrm{X}_{\mathrm{i}}=$ Maximum score

$\mathrm{X}_{\mathrm{n}}=$ Minimum score

Calculation results are needed to determine consumer responses to organic products, as in Table 1.

Table 1. Categories of Consumer Response for Organic Agricultural Products

\begin{tabular}{ccc}
\hline No. & Value of Intervals & Consumer Response \\
\hline 1. & $\geq 14-32$ & Not good \\
2. & $>32-50$ & Good \\
3. & $>50-68$ & Very Good \\
\hline
\end{tabular}

\section{RESULTS AND DISCUSSION}

\section{Production Side Organic Agriculture Scanning}

Several previous studies have shown that the use of organic materials has succeeded in increasing product quality, but not significant to increase productivity. However, the study of the application of organic fertilizers processed with bacterial technology succeeded in improving the previous organic material application technology. The technology for using bacteria, in addition to improving soil structure, has also improved the ability of the soil to provide plant nutrients in a sustainable manner (Hartatik, W., Husnain, 2015; Manullang, GS, A. Rahmi, 2014; Pujiasmanto, B., P. Sunu, Toeranto, 2009).

Based on the empirical experience above, the Musi Rawas University Experimental Garden in Muara Beliti conducted an organic fertilizer with the main ingredient of factory crumb rubber waste plus vegetable waste, straw, cattle dung, and straw. By using organic decomposing bacteria (PBO), the soil which had initially lost its processing layer, and even peeled off, looks increasingly loose structure and turns black, and productive.

Table 2. Minimization of Cost of Organic Fertilizer Manufacturing for Four Types of Plants in the Agrotrisula Experimental Garden Unmura-Muara Beliti

\begin{tabular}{lrrrrrrrr}
\hline \multirow{2}{*}{ Organic Material } & \multicolumn{2}{c}{ Sweet Corn } & \multicolumn{2}{c}{ Spinach } & \multicolumn{2}{c}{ Kale } & \multicolumn{2}{c}{ Long Beans } \\
\cline { 2 - 10 } & \multirow{2}{*}{ Value } & $\begin{array}{c}\text { Lower } \\
\text { Bound }\end{array}$ & \multirow{2}{*}{ Value } & $\begin{array}{l}\text { Lower } \\
\text { Bound }\end{array}$ & \multirow{2}{*}{ Value } & $\begin{array}{r}\text { Lower } \\
\text { Bound }\end{array}$ & Value & $\begin{array}{r}\text { Lower } \\
\text { Bound }\end{array}$ \\
\hline Waste Rubber Factory & 83,333 & 000 & 40,000 & 0 & 30,000 & 0 & 50,000 & 0 \\
Rice Straw & 000 & 6.67 & 0 & 6.67 & 0 & 6.67 & 0 & 6.67 \\
Waste Vegetable & 000 & 7.78 & 0 & 7,78 & 0 & 7.78 & 0 & 7.78 \\
Husk & 0 & 38.89 & 0 & 38.89 & 0 & 38.89 & 0 & 38.89 \\
Goat Manure & 0 & 166.67 & 0 & 166.67 & 0 & 166.67 & 0 & 166.67 \\
\hline
\end{tabular}


This study tries to use the LP model to minimize costs. Through this method, a single formulation of organic fertilizer (rubber factory waste) is obtained for a minimal cost solution, and compound organic fertilizer (rubber factory waste, straw, vegetable waste, and goat manure). The details are presented in Table 2. Table 2 shows that the minimum costs to meet the needs of the four types of plants produce a formulation that only uses rubber waste as organic material (single formulation), each for each hectare: 83 tons of sweet corn, 40 tons of spinach, 30 tons of Kale and 50 tons of Long Beans. Other ingredients are zero, which means steps. This means that the addition of rubber factory waste causes excessive use, but if the availability of rice straw, vegetable waste, husk, and goat manure is sufficient, then the four materials may still be added (see lower bound) by reducing the use of rubber mill waste. The addition of organic material sources to form compound compounds is presented in table 3 .

Table 3. Formulation of Organic Fertilizer with Addition of Rice Straw, Waste Vegetable, Husk, and goat manure

\begin{tabular}{|c|c|c|c|c|c|c|c|c|}
\hline \multirow[b]{2}{*}{ Raw Materials } & \multicolumn{4}{|c|}{ Supplies (kg/ha) } & \multicolumn{4}{|c|}{ Requirement (kg plot trial) } \\
\hline & $\begin{array}{l}\text { Sweet } \\
\text { Corn }\end{array}$ & Spinach & Kale & $\begin{array}{l}\text { Long } \\
\text { Bean }\end{array}$ & $\begin{array}{c}\text { Sweet } \\
\text { Corn }\end{array}$ & Spinach & Kale & $\begin{array}{l}\text { Long } \\
\text { Bean }\end{array}$ \\
\hline 1. Waste Rubber Factory & 83.112 & 39.779 & 29.779 & 49.649 & 39,779 & 56.00 & 42.00 & 199.00 \\
\hline 2. Straw & 7 & 7 & 7 & 67 & 0.03 & 0.01 & 0.01 & 0.27 \\
\hline 3. Waste Vegetable & 8 & 8 & 8 & 78 & 0.03 & 0.01 & 0.01 & 0.31 \\
\hline 4. Husk & 39 & 39 & 39 & 39 & 0.04 & 0,04 & 0.04 & 0.16 \\
\hline 5. Goat Dirt & 221 & 221 & 221 & 351 & 0.67 & 0.67 & 0.23 & 1.40 \\
\hline
\end{tabular}

Prompts to add other materials besides rubber factory waste into fertilizer formulations are technically recommended. Because, in fact, field observations show that the basic ingredients of organic fertilizer in the form of straw, vegetable waste, husks, and goat manure, are abundant raw materials in the field. As it is known that the area is the center of rice field and lowland vegetables, besides having superior goat livestock products. The two formulations above were applied to separate experimental plots in the agrotrisula experimental garden. Then the data were analyzed farming performance, as shown in Table 4.

Table 4. Comparative Analysis of Some Plant-Based Organic Fertilizer Formulations Applications per Unit Experiment $^{1}$

\begin{tabular}{lrrrrrrrr}
\hline & \multicolumn{2}{c}{ Sweet Corn } & \multicolumn{2}{c}{ Spinach } & \multicolumn{2}{c}{ Kale } & \multicolumn{2}{c}{ Long Bean } \\
\cline { 2 - 9 } Description $^{2}$ & $\begin{array}{c}\text { Compound } \\
\text { Formulation }\end{array}$ & $\begin{array}{c}\text { Single } \\
\text { Formulation }\end{array}$ & $\begin{array}{c}\text { Compound } \\
\text { Formulation }\end{array}$ & $\begin{array}{c}\text { Simple } \\
\text { Formulation }\end{array}$ & $\begin{array}{c}\text { Compound } \\
\text { Formulation }\end{array}$ & $\begin{array}{c}\text { Siingle } \\
\text { Formulation }\end{array}$ & $\begin{array}{c}\text { Compound } \\
\text { Formulation }\end{array}$ & $\begin{array}{c}\text { Singple } \\
\text { Formulation }\end{array}$ \\
\hline 1. Production & 60 & 28 & 402 & 335 & 288 & 250 & 169 & 130 \\
2. Price & 7,000 & 7,000 & 1,200 & 1,200 & 700 & 700 & 5,000 & 5,000 \\
3. Revenue & 420,000 & 196,000 & 482,400 & 402,000 & 201,600 & 174,999 & 845,000 & 650,000 \\
\hline 4. Cost & 314,365 & 159,165 & 314,239 & 314,165 & 102,590 & 102,590 & 456,247 & 456,247 \\
Fixed Cost & 14,165 & 14,165 & 14,165 & 14,165 & 14,170 & 14,170 & 21,390 & 21,390 \\
Var. Cost & 300,200 & 145,000 & 300.074 & 300,000 & 88,494 & 88.420 & 435,134 & 434,857 \\
\hline 5. Profit & 105,635 & 37,000 & 168,161 & 87,835 & 98,660 & 72,409 & 388,753 & $53,764,36$ \\
\hline 6. Basic Prices & 5,239 & 5,684 & 782 & 938 & 356 & 410 & 2,700 & 3,510 \\
\hline 7. R/C & 1.34 & 1.23 & 1.54 & 1.28 & 1.96 & 1,71 & 1.85
\end{tabular}

Explanation: 1. Size of the experimental unit of sweet corn and long beans g $40 \mathrm{~m}^{2}$, spinach and spinach $14 \mathrm{~m}^{2}$

2. Production ( $\mathrm{kg} / \mathrm{unit}$ trial), price (IDR/kg for sweet corn and long beans, and IDR/trial for spinach and kale, and costs and profits IDR/unit experiment

Table 4 shows that from the production side it turns out that all types of plants that use organic fertilizer compound formulations have better farming performance compared to those applying organic fertilizer with a single formulation. The indications are that all production performance, revenue, profit, cost of goods, and R / C of plants that apply compound-based organic fertilizer formulations are better than plants that apply single formulation organic fertilizer.

Hal 43 Volume 5 Nomor 1, Tahun 2021 
Seen from the R/C side, it can be seen that the application of compound formulated organic fertilizer in plants is relatively riskier than the application of single formulation organic fertilizer. This can be seen from the $\mathrm{R} / \mathrm{C}$ value of plants that apply a compound formulation organic fertilizer is higher than the application of a single formulation organic fertilizer. However, with the lower cost of goods, it means that the farming business that applies compound organic fertilizer has higher competitiveness, which can reduce the risk if there is a price decline.

The above findings show that the additional cost of applying compound organic fertilizer formulations causes increased productivity and revenue. This means that the elasticity of production increases is still in the irrational region III, or when it is irrational if the addition of production factors is stopped (Suparmoko, M., 2014). The essence of this finding shows that the key to the elasticity of production plays an important role in farming activities. Therefore, the question arises, why does the application of compound organic fertilizer show a high production elasticity? To answer the question, we need actual facts that occur on the ground in the field.

Field findings show that when the soil applies a single formulation of organic fertilizer, the organic material decreases. The indication, soil color begins to approach the initial color before any treatment. However, on the other hand, soils that are treated with organic fertilizer with compound formulations are still brownish-black, and still leave rice husk as one of the sources of raw materials for compound formulations. This fact can be a reference to conclude that organic fertilizer shows that organic fertilizer is a compound formulation, releasing nutrients to be absorbed by plants slowly so that it is absorbed effectively and efficiently. In addition, indicators of soil color and blackened chaff remain not decomposed, indicating Corganic levels are still high, and soil microorganisms are still at work. This finding is in line with research by (Prabowo, R., 2017; Yunus, F., O. Lambui, 2017) that dark-colored soils, which still contain dark organic matter, indicate high levels of fertility and micro-organism activity.

\section{Scan from the Marketing Side}

Of the market side, some previous research results show that consumer demand for organic agricultural products is still limited to consumers with middle to upper income, and groups with relatively high education and knowledge. Amin (Z. A. Amin, 2015) and Paraiba, Mappatoba, and Lamusa (Paradiba, D., M. Mappatoba, 2017) show that consumer preferences for agricultural products are largely determined by purchasing power and product prices, besides that the higher the education of consumers, the preference for products tends to lead to quality products, both in terms of taste, nutrition and safety food.

Scanning in marketing channels in this study further strengthens the results of the above research. It is said so because only 20 percent of these products are marketed directly to consumers with education and income levels that are classified as middle to upper, the rest are marketed through intermediary traders at prices below the average price. The Marketing Chain of Organic Agriculture Products at Unmura Agrotrisula Experimental Garden is presented in Figure 2.

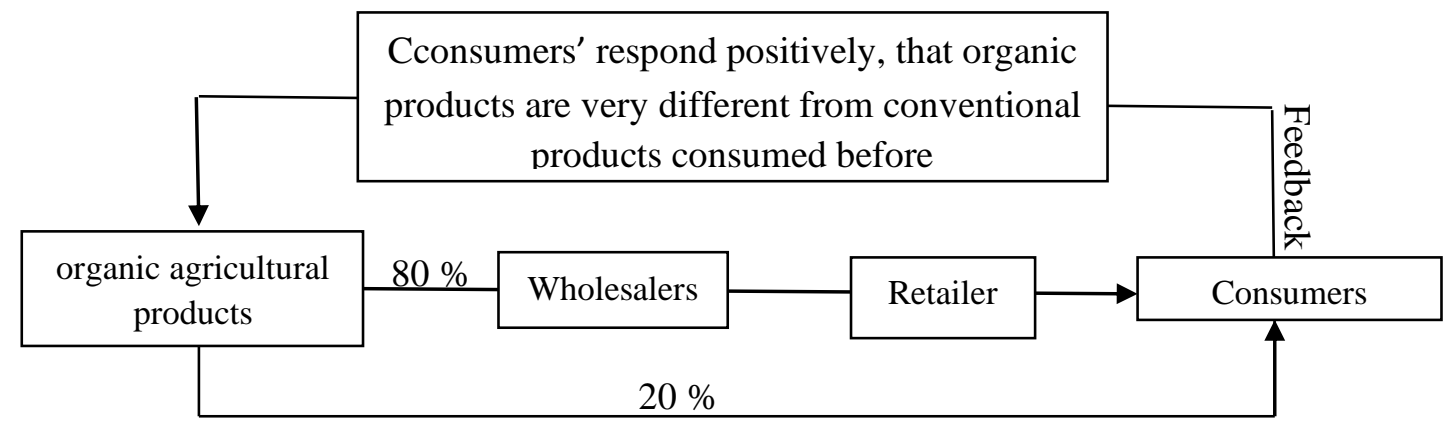

Figure 2. Marketing Channels of Organic Agriculture Products and Consumer Responses to Organic Products 
Figure 2 shows that only $20 \%$ of organic products are distributed directly to end consumers, most of which is the academic community of Musi Rawas University, and beyond that, only a small portion. This means that, consumers who buy or consumers who are willing to buy above the average price of only $20 \%$. The rest, organic products are sold at collectors whose prices are the same as conventional agricultural products. This means that in order to reach the final consumer factually, producers are still dependent on intermediary traders. For the sake of marketing effectiveness and efficiency, it is necessary to cut the value chain through strong farmer institutions. This condition, from the producer side, is often detrimental, due to market concentration, so producers sell below the equilibrium price. This is consistent with Amin's research (Zaini amin, 2014); and Amin and Andry(Z. A. Amin, 2015) the existence of market concentration in marketing has caused the prices received by producers to be below the equilibrium price.

Furthermore, still related to Figure 2, it was found that in terms of consumers as a whole, consumer responses to organic agricultural products are very good. There are 14 attributes used in assessing consumer responses to organic agricultural products (Table 4).

Table 4. Consumers' Responses to Organic Agricultural Product

\begin{tabular}{clcccccc}
\hline \multirow{2}{*}{ No. Statement } & & \multicolumn{3}{c}{ Response (People) } & \multicolumn{2}{c}{ Score } \\
\cline { 3 - 6 } & & SS & S & CS & TS & STS & Mean \\
\hline 1. & The level of cleanliness is guaranteed & 42 & 8 & 0 & 0 & 0 & 4,840 \\
2. & Looks fresh & 40 & 10 & 0 & 0 & 0 & 4.800 \\
3. & More uniform & 00 & 36 & 14 & & 0 & 3.720 \\
4. & Crisper of products the other & 41 & 9 & 0 & & 0 & 4.820 \\
5. & the taste is sweeter & 39 & 11 & 0 & 0 & 0 & 4.780 \\
6. & not easily wither & 38 & 12 & 0 & 0 & 0 & 4,760 \\
7. & Prices are no different & 48 & 2 & 0 & 0 & 0 & 4.960 \\
8. & Still affordable & 36 & 14 & 0 & 0 & 0 & 4.720 \\
9. & Practical in providing consumption & 0 & 0 & 30 & 20 & 0 & 2.600 \\
10. & Suitable for all ages & 32 & 18 & 0 & 0 & 0 & 4.640 \\
11. & Environmentally friendly & 0 & 30 & 20 & 0 & 0 & 3.600 \\
12. & Easy to obtain & 0 & 0 & 28 & 22 & 0 & 2.560 \\
13. & Can be provided in traditional markets & 0 & 0 & 35 & 15 & 0 & 2.700 \\
14. & Good for health & 0 & 35 & 19 & 0 & 0 & 3.940 \\
\hline
\end{tabular}

Table 4 shows that all consumer statements respond positively to marketed organic agricultural products. The score of consumer statements on organic agricultural products is generally greater than four. An indication that the comparison of organic agricultural products with conventional agricultural products is that the price of organic products is no different, hygiene is guaranteed, crisper looks fresher, tastes sweeter, does not wilt easily, prices are still affordable, suitable for all ages, good for health, more uniform, and environmentally friendly. Then, a small number of consumers still doubt that organic agricultural products can be provided in traditional markets, are practical in supply, and are easily available. The essence of this indication is how to provide organic agricultural products at affordable prices on the consumer side, and competitive prices on the producer side?

This finding shows that in terms of production, as explained earlier that organic agricultural products are feasible to be cultivated. The reason, because, organic agricultural products produced have a competitive edge. The indicative cost of goods produced is more than the average price in effect; and fertilizer needs can be provided by farmers, with locally available raw materials. In the previous study (Ameriana, 2006; Z. Amin et al., 2020; Paradiba, D., M. Mappatoba, 2017) explained that the problem of consumers in consuming organic agricultural products is located in the level of income (budget), and price. Consumers 
who consume organic products are only limited to consumers with middle to upper-income scale because the prices of organic products tend to be higher than conventional agricultural products.

The essence of the above findings is that organic agricultural products are feasible to be cultivated on a large scale with minimum costs, competitive prices, and are able to be reached by consumers widely. It's just that institutions need to be able to cut the value chain so that marketing results can be more effective and more efficient.

\section{CONCLUSIONS}

Based on the results of research and discussion, it can be concluded that, in terms of farm production and analysis, the provision of more competitive production, indicated by high crop productivity, and minimal fertilizer costs, because it is made from local raw materials using technology bacteria; and from the market side, it shows that $80 \%$ of distribution takes place through channels that require the services of intermediary traders, and consumer responses show that organic farming products are better than conventional agricultural products that they previously consumed. Therefore, it is recommended to disseminate organic farming technology broadly, and there need to be strong farmer institutions to cut the value chain in distribution to end consumers.

\section{REFERENCES}

Ameriana, M. (2006). Kesediaan Konsumen Membayar Premium Untuk Tomat Aman Residu Pestisida. Jurnal Hortikultura, 16((2)), 165-174.

Amin, Z. (2016). Rice Consumer Behavior In The Musi Rawas District. International Conference on Agribusiness Development for Human Welfare, 272-278. Yogyakarta: Departement Of Agribusines, Faculty of Agriculture, Universitas Muhamadiyah Yogyakarta.

Amin, Z. A. (2015). Bargaining Position of Farmers in Tilapia Marketing. 4th AIMI International Conference Proceeding., ISBN: 978-602-7677-80-7. 256 - 286.

Amin, Z., Andry, Humaidi, E., Wahyuni, N., \& Ningsih, V. Y. (2020). Consumers' perceptions and willingness to pay (WTP) organic rice. Journal of Critical Reviews, 7(1), 48-51. https://doi.org/10.22159/jcr.07.01.08

Hartatik, W., Husnain, and L. W. (2015). Peranan Pupuk Organik dalam Peningkatan Produktivitas Tanah dan Tanaman. Jurnal Sumberdaya Lahan, 9((2)), 107-120.

Humaidi, E., \& Amin, Zaini, N. S. (2015). Pola Pengeluaran Rumah Tangga Petani Karet Di Desa Binjai Kecamatan Muara Kelingi. SOCIETA, IV(1), 54-58. Retrieved from https://www.google.com/url?sa=t\&rct=j\&q=\&esrc=s\&source=web\&cd=1\&cad=rja\&uact=8\&ved=2ah UKEwj0u8XJ_I_iAhWMQo8KHXQ5BAkQFjAAegQIARAB\&url=http://jurnal.umpalembang.ac.id/societa/article/view/227\&usg=AOvVaw20_6heScNBZxeP7z9fZVL6

Iqbal, M. (2015). Consumer Behavior of Organic Food: A Developing Country Perspective. International Journal of Marketing and Business Communication, 4:, 50-68.

Kumar, P., A. Kumar, S. P. and S. R. (2012). Estimation of demand elasticity for food commodities in India. K Agricultural Economics Research Review, 24((1):), 1-14.

Manullang, GS, A. Rahmi, andP. A. (2014). Pengaruh Jenis Dan Konsentrasi Pupuk Organik Cair terhadap Pertumbuhan dan Hasil Tanaman Sawi (Brassica Juncea L.) Varietas Tosakan. 
Paradiba, D., M. Mappatoba, and A. L. (2017). Faktor-faktor yang Mempengaruhi Permintaan Sayur Organik di Kota Palu. E-J Agribisnis, 5((5):), 564-571.

Prabowo, R., and R. S. (2017). Analisis Tanah sebagai Indikator Tingkat Kesuburan Lahan Budidaya Pertanian di Kota Semarang. Jurnal Cendikia Eksakta, 2((2):), 59-64.

Pujiasmanto, B., P. Sunu, Toeranto, and A. I. (2009). Pengaruh Macam dan Dosis Pupuk Organik Terhadap Pertumbuhan dan Hasil Tanaman Sambiloto (Andrographis Paniculata Ness.). Jurnal Ilmu Tanah Dan Agroklimatologi, 6((2):), 81-90.

Qua, S.H., and A. K. . T. (2010). Consumer Purchase Decisions of Organic Food Products: An Ethnic Analysis. Journal of International Consumer Marketing, 22:, 47-58.

Sivathanu, B. 2015. (2015). Factors Affecting Consumer Preference towards the Organic Food Purchases. Indian Journal of Science and Technology, 8((33):), 1-6.

Suparmoko, M., F. Y. (2014). Ekonomika untuk Manajer. Ekonomia Manajerial. Bogor: Penerbit In Media,.

Umar, H. (2002). Penelitian dalam Aplikasi Pemasaran. Jakarta: Penerbit PT Gramedia Pustaka Utama,.

Yunus, F., O. Lambui, I. S. (2017). Kelimpahan Mikroorganisme Tanah pada Sistem Perkebunan Kakao (Theobroma cacao L.) Semi-intensif and non-intensif. Journal of Science and Technologist, 6((3):), 194-205.

Amin Z . (2014). Konsentrasi Pasar dan Posisi Tawar Petani Kelapa Sawit dalamPemasaran Tandan Buah Segar (TBS). Jurnal of Societa, 3((2)), 83-88. 